\title{
A NEED ANALYSIS OF INNOVATIVE CULTURE-BASED ENGLISH LEARNING MODEL FOR NON-ENGLISH DEPARTMENT STUDENTS AT BINA NUSANTARA UNIVERSITY
}

\author{
Aryusmar $^{1}$, Muhartoyo ${ }^{2}$ \\ ${ }^{1}$ Bina Nusantara University, Indonesia \\ ${ }^{1}$ aryusmar@yahoo.com \\ ${ }^{2}$ Bina Nusantara University, Indonesia \\ 2ymuhartoyo@yahoo.com
}

\begin{abstract}
In line with Binus University mission the graduates are expected to get involved themselves in the global community by either working for global companies or being selfemployed professionals or entrepreneurs with world-wide perspective. This can only be successfully achieved when their graduate competence includes the ability in using English for global professional communication. English is widely used in activities of economy, trade, industry, education and culture. This paper presents a need analysis of non-English Department students at Bina Nusantara University to acquire English language and culture simultaneously. The analysis is based on the experience of teaching English for nonEnglish Department students at Bina Nusantara University and based on the analysis of compiled concepts, theories and references obtained through comprehensive library research. The need analysis concludes that there is an urgent need to develop an Innovative Culture-Based English Learning Model to Enable Non-English Department Students at Bina Nusantara University to Master English Language for Professional Development. New learning culture also needs to be introduced to achieve the learning outcomes set out in the Culture-based Learning model.
\end{abstract}

Keywords: need analysis, non-English Department students, English graduate competence, culture-based English learning model

\section{INTRODUCTION}

English is one of compulsory subjects for university students in Indonesia, including Bina Nusantara University as English is an international language as well as language for science and technology. Large numbers of scientific information are presented in English, therefore mastering English will lead to the wider opportunities to acquire scientific knowledge. To succeed in English education needs improved teaching and learning activities supported by quality human resources coupled with a sound learning method. In other words, the improvement of human resources and good learning method will have positive impact to English learning process. For this reason, a learning model which induces the transformation of student learning culture, improved motivation and interest in using English as well as to understand both local and global culture needs to be developed.

Recently issues on the limited English proficiency of university graduates have been lurking around. This limitation is most likely caused by unsuccessful English teaching in University level. There are many factors behind the problems, one of them is the English learning model which does not give emphasis on the function of English as communication tool. Too much emphasis was given to the mastery of grammatical structure and reading.

As is the case with non-English department students, most English learning models emphasize the mastery of four language skills including reading, listening, writing, speaking. In addition, English teaching also emphasizes grammar and 
vocabulary. Students' English proficiency is often measured through the TOEFL (Test of English as a Foreign Language) test or IELTS (International English Language Testing System). It is true that high TOEFL or IELTS test scores are necessary for students who intend to continue their education to English-speaking countries such as America, the UK and Australia. However, there is a gap for the graduates who do not intend to pursue further education in English speaking countries. These graduates need English for verbal communication to support their career. The above mentioned models seem to be lacking in developing students skill in using English for communication. Therefore, an innovative English learning model which incorporates culture in it is worth considering. Culture is nonlinguistic factor that plays vital role in making students more capable in using English for communication.

Cultural aspect has not received attention in learning English for non English Department students. As a matter of fact cultural aspects are very important to be understood by students in learning English because the cultural aspect is one element of the language itself. In this case there is a significant relationship between culture and language. It is not enough to learn English without learning the cultural aspects of the target language being studied. By learning the culture of the English does not necessarily mean accepting and adopting the western culture in their life. The cultural understanding will enable the students to communicate in English more properly.

In communication exchange using English, grammatical errors may still be very acceptable to foreigners, but the use of language that is incompatible with culture can be fatal. As an example when we ask a foreigner at the first meeting "how old are you?", there is no grammatical mistake in the sentence, but in the western culture asking age is something which is not polite, thus not acceptable. In western cultures like Britain and America, the issue of "age" may be a fairly sensitive personal issue and should therefore be avoided for questioning.

Cultural issues such as the above example may not have been included in English language learning for non-English department students. Therefore nonEnglish department students need to be equipped with cultural insights to avoid misunderstanding in using English for communication.

From the description above it can be seen how important the understanding of culture in learning English is. In addition to overcoming misunderstanding in communication caused by cultural differences, cultural understanding can also be a means to enhance learners' awareness with their culture which is not the same as the culture of the target language. Finally, the awareness of these cultural differences can foster tolerance in learners.

This paper presents a need analysis as an initial step to conduct in-depth research on innovative culture-based English learning model for non-English department students at Binus University.

\section{LITERATURE REVIEW}

\subsection{Learning Model}

Joyce \& Weil (1980) defines the learning model as the conceptual framework used as a guide in learning. Thus, the learning model is a conceptual framework that depicts a systematic procedure within organized learning experiences to achieve learning objectives. In addition, Joyce \& Weil (1980) also added that the learning model has five basic elements (i.e. (1) syntax, i.e. learning operational steps, (2) social system, is the prevailing atmosphere and norms in learning, (3) 
Principles of reaction, describes how teachers should view, treat, and respond to students, (4) support systems, any means, materials, tools, or learning environments that support learning and (5) instructional and nurturant effects - learning outcomes which is directly obtained based on targeted instructional effects and learning outcomes which are outside targeted effects (nuturant effects). Effective learning model is a learning model that has a theoretical basis that is humanistic, flexible, adaptive, contemporarily oriented, has a simple syntax of learning (pattern sequence), is easy to do, and can achieve the learning outcomes. Each learning model begins with an effort to attract students' attention and motivate students to get involved in the learning process and ends with the closing stage of the lesson, in which the activities include the summarizing of the lessons learned by students with teacher guidance.

One technique developed in innovative learning model according to the above model is question and answer technique and presentation. This technique begins with questioning each other and answering questions, after completing each other's questions and answering questions, they present in front of the class. From the observation this technique turns out to be very much attractive for students to improve their English communication skills.

\subsection{The Importance of Culture and English Learning}

A number of prominent linguists have stated that culture and language cannot be separated each other as they are very closely related. Therefore a lot of attention has been given to the development of cross-cultural communication skills. It is argued that teaching English without involving culture is considered to be inaccurate and incomplete. Kitao (2000) in (Doganay, 2013:108-109) giving reference to several authors lists some of the benefits of teaching culture as follows:

- Studying culture gives students a reason to study the target language and can be a good motivational tool.

- One of the major problems in language teaching is to enable students think in the language they learn.

- Providing access into cultural aspect of language, learning culture would help learners relate the abstract sounds and forms of a language to real people and places (Chastain, 1971).

- The role of motivation was proved in ELT it is by experts like Gardner and Lambert (1959, 1965, and 1972). In achieving high motivation, culture classes do have a great role because learners like cultural based activities such as singing, dancing, role playing, discussing about and doing research on countries and peoples, etc.

- The use of cultural based activities in language education increases learners' not only curiosity about and interest in target countries but also their motivation.

Yakup Doganay in his study on the Impact of Cultural-Based Activities in Foreign Language Teaching at Upper Intermediate (B2) level proved that practicing various cultural based tasks students was able to develop communicative skills as well as to expand their sense of cross-cultural awareness. The results of the data obtained from the data collection instruments showed that the cultural based activities have an effective influence on the development of linguistic competency of learners as well as communicative competency (Doganay, 2013: 112).

According to Frank (2013) simply having an acquaintance with the grammar, syntax, phonetics, and some of the social conventions associated with English will 
not give learners real insights into the nuances of the daily lives of the people whose language they hope to speak. Therefore culture must be included in the English learning. However, currently there is a lack of consensus on how introduce cultural elements in the language learning. Frank further states that one way to foster curiosity and openness to English-speaking cultures is to establish a "collection" of cultural information in a variety of formats. These could include popular movies, music, literature, online sites, and everyday items like stamps, currency, toys, musical instruments, menus, travel brochures, magazines, and newspapers from English-speaking countries — or from a specific country, depending on student needs and course goals. "However, as the world becomes more interconnected, we must help our students understand that it is more important than ever for them to be able to activate their "cultural antennas" to understand not only other cultures, but their own as well." (Frank 2013).

Larsen-Freeman stated that many language teachers acknowledge the need to integrate the language and culture; yet she thinks that it is fair to say that there really is no well-articulated theory of culture that has informed our English teaching field during the last 25 years, and hence that the means of teaching culture to language students have not been well developed (Larsen-Freeman, 2012). She further stated that many applied linguists who hold the perspective of English as international language value the pluralism that exists in the English-speaking world (Indian English, Singaporean English, Nigerian English, etc.) and feel that one can be bilingual without being bicultural, that one can and should learn English for utilitarian purposes without adopting the dominant target culture.

Many English teachers agree that a cultural component should be included in the teaching of English. Citing Adaskou, Britten, and Fahsi (1990) in McKay (2003) summarizes the following arguments for having a cultural component in language teaching: it can promote international understanding, deepen an understanding of one's own culture, facilitate learners' visits to foreign countries, and motivate learners. She also contends that culture influences language teaching in two ways: linguistic and pedagogical. Linguistically, it affects the semantic, pragmatic, and discourse levels of the language. Pedagogically, it influences the choice of the language materials because cultural content of the language materials and the cultural basis of the teaching methodology are to be taken into consideration while deciding upon the language materials. For example, while some textbooks provide examples from the target culture, some others use source culture materials However, she reminds that traditionally, the cultural basis of English teaching has been closely linked to the culture of native-English-speaking countries, the fact that English has become an international language offers a serious challenge to this approach. In dealing with the linguistic and pedagogical aspect of culture in language teaching, what is needed is a full recognition that English today has become denationalized. Hence, it is local educators who need to determine what linguistic information, cultural content, and teaching methodology are most appropriate for the local context so that learners will be able to use English to tell others about their own culture (McKay, 2003).

Genc and Bada conducted a study on Culture in language learning and teaching ELT department of Çukurova University in Turkey. The purpose of this study was find out what students think about the effects of the culture class they attended in the fall semester of 2003-2004 academic year. They concluded that a culture class is significantly beneficial in terms of language skills, raising cultural awareness, changing attitudes towards native and target societies, and contribution to the teaching profession. Incorporating culture in the English curriculum would prove to be a vital component of language learning and teaching since it has a great 
deal to offer to the development of communicative competence as well as other skills in the instruction of any language (Genc \& Bada, 2005).

The need for the EFL (English as a Foreign Language) practitioners to equip their learners with an appropriate type of communicative competence within which both language and culture are encoded and decoded was presented by Elena Savu from Politehnica University of Bucharest. To be successful in cross-cultural interaction, people from different cultures should have cultural awareness as the way humans see, interpret and evaluate things is affected by their cultures. What is considered appropriate behavior in one culture is frequently inappropriate in other cultures. She argued that learning how to cope with a new experience from reassessed psychological, social and cultural perspectives can be a process of intellectual maturation and personal transformation. By embedding 'cultural' cues in teaching and learning how to write a letter of complaint using a text book titled English for Science and Technology, she tried to give a glimpse of a different way of participating in an interaction and achieving a communicative goal. It is obvious that no textbook perfectly integrates language and culture education, and language practitioners need to build up supplemental activities if they wish to make 'culture' learning a consistent component of their classes. Finally she concludes that culture and language are interwoven and cannot be actually separated in foreign language teaching and learning since, if any one of them is left out, the other remains incomplete (Savu, 2016).

\subsection{Various English and Culture Learning Models}

In a review of existing English learning methods it can be found that some English language teachers have incorporated cultural aspects into their English teaching methods. Nevertheless there is a difference in viewing the culture and learning methods as they are not intended for non-English department students. For example in Grammar Translation Method culture is only found in the discussion of literary and artistic texts, whereas culture is not only limited to literary and artistic texts but also to texts related to norms, habits, ways of thinking and so forth. In other words, this method does not accommodate cultural information more broadly.

The method that emerged after the Grammar Translation Method has begun to develop a broader concept of culture. For example, Direct Method views culture as more about literary and art works. This method has already begun to study culture that consists of the history of native speakers of the language being studied, the geographic region in which the language is used, as well as information about the daily lives of the native speakers. Not much different from Direct Method, Audio Lingual Method has also seen the culture of the behavior and lifestyle of native speakers. Even one of the teacher's responsibilities in this method is to provide information about the native speakers of the language being studied (Larsen-Freeman, 2000: 45). Silent Way even views culture as something inseparable from language. Each language has its own uniqueness that describes its society and culture is a reflection of the mindset of its people. In the Desuggestopedia culture is related to the daily life of the native speakers nevertheless the use of art is still important in this method (Larsen-Freeman, 2000: 83). Community Language Learning Method views culture as an integral part of language teaching. At Total Physical Response includes the lifestyle culture of a group of people who use the language natively. A view similar to the Total Physical Response Method of culture also appears in the Communicative Language 
Teaching Method. Some of the teaching methods that emerged after the Grammar Translation Method have almost the same view on culture.

In addition to literature cited above, the development of innovative culture-based English language learning for non-English department students in this study will also refer to the learning pillars developed by UNESCO which has designed several learning pillars, i.e. learning to do, learning to know, learning to $\mathrm{Be}$, and learning to live together. In this case, Learning to do means that learning is conducted to empower learners to be willing and to be able to enrich their learning experience. Learning to know is a learning process designed by intensifying the interaction with the environment including physical, social and cultural environments so that learners are able to build understanding and knowledge of the world around it. Learning to be is a learning process that students are expected to be able to build their knowledge and confidence. Learning to live together is that learning which is directed more toward the effort to shape the personality to understand and recognize diversity so as to create positive attitudes and behaviors in responding to differences or diversity.

Furthermore, there is a paradigm shift in language learning, where teachers, textbooks, and teaching methods are no longer placed as the main factors for achieving success in language learning. The Language Learning Principles of this paradigm say: "Successful mastery of the second language will be due to a large extent to a learner' s own personal "investment" of time, effort, and attention to the second language in the form of an individualized battery of strategies for comprehending and producing the language" (Brown, 2001:60). Thus success in language learning is largely determined by learning strategies of language learners in understanding and producing language. Meanwhile Spratt (2005) defines the following learning strategies: "Learning strategies are the ways chosen by learners to learn language. They include ways to help students identify what they need to learn, process new language and work with other people to learn. Using the right strategy at the right time can help them learn the language better, and help to make them more autonomous."

Then, Richard and Schmidt, 2002 mention that in general the learning style can be divided into 4 categories: a) Cognitive strategies, for example by analyzing the target language (in this case English language), comparing new things with what is already known both in the first language and the second language, and organizing information. b). Meta cognitive strategies, such as paying attention to how they learn, making well-organized plans, monitoring personal development. c). Social strategies, such as looking for friends who are also native speakers of the language being studied (English) or working groups in the classroom. d). Resource management strategies, such as designing regular time for learning and determining where to learn.

\section{METHODS}

The method used to solve the problems raised in this paper is by descriptive approach based on the need analysis and relevant references collected for this study and experiences in teaching English for non-English department at Bina Nusantara University.

There are many definitions of needs analysis according to linguists. Haque, N. (2014:2349) has compiled several definitions of needs analysis as follows: a) Nunan, D. (1983) defines need analysis as "techniques and procedures for collecting information to be used in syllabus design". b) Richards, J. (1992) states 
that it is "the process of determining the needs for which a learner or a group of learners requires a language and arranging the needs according to priorities . c) Fatihi, A.R. (2003) explains that it is " a device to know the learner's necessities, needs and lacks". d) Brindley, G. (1984) defines it as "learner's wants , desires, demands, expectations, motivations, lacks, constraints and requirements". Based on those definitions it can be summed up that need analysis is a tool used for finding out leaner's motivations, expectations constraints and requirements concerning their English graduate competence.

\section{FINDINGS AND DISCUSSION}

The current English lessons for non-English department students at Bina Nusantara University are divided into 4 different levels. The lowest level is called English In focus, the second level is English Savvy, the third is English for Business Presentation, and the highest level is English for Written Business in which the lower level is the prerequisite for taking the higher level. The placement for each level is based on students' TOEFL score. Students with the TOEFL score below 432 have to join English In focus. Those with the TOEFL score ranging from 433 to 463 can skip English In focus and go straight to English Savvy, and those with TOEFL score more than 464 can skip both English In focus and English Savvy and take English for Business Presentation which is the prerequisite for taking English for Written Business. The Course Outlines of the English Savvy can be seen in the attachment of this paper as a reference.

Observing the learning outcomes and graduate competences of these English learning models, it was found that the emphasis is given to the mastery of the four language skills i.e. Reading, writing, speaking and listening. These four language skills are developed using TOEFL materials. English language laboratory is provided for students who want to practice and improve their TOEFL test taking strategies. In addition, special emphasis is given to the mastery of business English. Having observed these existing English learning models, it can be concluded that the focus of English learning is on the mastery of language and cultural elements do not get any place in these learning models. The problem is the high TOEFL score may indicate the mastery of the English language, but do not necessarily show the communication ability.

As previously mentioned in the literature review, learning language cannot be separated from culture. Students will have better motivation when they learn the language and culture at the same time. Culture-based activities have been proved to be quite motivating for English learners as the learning process is not boring any more. Culture-based activities which include role playing, discussing about and doing research on countries, and peoples' customs habits and customs will be generate more interest among students. Through these activities students will be encouraged to develop their communication skills.

Steinberg (2001: 190) also states that the method of learning a foreign language can be seen from several things such as: the focus of language teaching, the teaching of meaning, the teaching of grammar. In other words, the current learning method is more directed to the mastery of the language rather than on the development of communication skills. Therefore, what is very urgent to be developed now is Innovative Learning Method that will enhance the ability of students from non-English Department to communicate using English properly. To achieve this purpose it is necessary to incorporate cultural aspects in the development of English learning model in order that the way they communicate using English is acceptable and in accordance with the culture of native speakers. 
Another reason is that someone can construct a sentence well and grammatically correct when communicating, but the sentence may not necessarily be accepted with the culture of the speaker. Therefore, it is necessary to develop an innovative English learning model that takes into account the culture of the language being studied.

Based on the need analysis above the development of Innovative Culturebased English Learning Model in Bina Nusantara University is quite possible because it is in line with its mission to make its graduates get involved in the global community. The involvement can be conducted by working in a global company or to become self-employed professionals and entrepreneurs with global perspective and networking. This new model will contribute to the realization of graduate competence set out by the University.

With the Innovative Culture-based English Learning Model, students are trained to be more active and independent. The lecturer will become facilitator and resource persons for the students. To achieve this purpose, students will be equipped with retrieval skills so that they become searching learners. Retrieval skill covers the understanding of various sources of information and the ability of using retrieval tools such as Indexes, Abstracts, Catalogues, and data bases. With this retrieval skills, they can enrich or expand their knowledge by searching both printed or digital information in the library and Internet.

\section{CONCLUSION}

The literature review and need analysis above have led to the conclusion that culture should not be separated from English learning. Learning language without culture is incomplete. Therefore Innovative Culture-based English Learning Model needs to be developed and implemented. This newly introduced English Learning Model will train non-English department students to master the English language and to have inter-cultural awareness and skills at the same time. Both skills are necessary for the professional development.

The development and implementation of this model is quite possible because it supports the mission of the Bina Nusantara University to be World Class University that produces quality graduates who work in a global company or to be self-employed professionals with global perspective and world-wide networking.

As this new learning model requires students to be more active and independent, students will be trained to be a searching learner. To achieve this, they will be equipped with information retrieval skills. As searching learners they have to be familiar with libraries systems and its various retrieval tools for both printed and digital information so that their information seeking behavior will be improved.

\section{REFERENCES}

Brown, H. D. (2001). Teaching by principles: An interactive approach to language pedagogy. N.Y: Longman.

Doganay, Y. (June 10, 2013). The Impact of Cultural Based Activities in Foreign Language Teaching at Intermediate (B2) Level. Educational Journal 2 (4): $108-113$

Frank, J. (2013). Raising Cultural Awareness in the English Language Classroom. English teaching forum, 51(4), 2-35

Genc. B., Bada, E. (April, 2005). Culture in Language Learning and Teaching. The Reading Matrix 5 (1): 73-83 
Haque, N. (January, 2014). A brief study on need analysis. Express, an International Journal of Multidisciplinary Research, 2 (1): 2348-2052

Joyce, B., \& Weil, M. 1980. Model of teaching. New Jersey: Prentice-Hall, Inc Larsen-Freeman, D. (2012). From Unity to Diversity: Twenty-five Years of Language-Teaching Methodology. English teaching forum, 50(2), 28-38

McKay, S.L. (2003). The cultural basis of teaching English as an international language. TESOL Matters Vol. 13 No. 4

Richards, J. C., Schmidt, R. (2002). Longman Dictionary of Language Teaching and Applied Linguistics. London: Longman Pearson Education.

Savu, E. (2016). Intercultural awareness in teaching English as a foreign language in Multicultural Representations: Literature and Discourse as Forms of Dialogue. Tirgu Mures: Archipelago XXI Press

Spratt, M., et. al. 2005. Teaching Knowledge Test. Cambridge: CUP.

Steinberg, Danny D, Hiroshi Nagata, David P Aline. 2001. Psycholinguistics Language, Mind and World. Second Edition. London: Longman. 


\section{ATTACHMENTS}

\section{English Savvy-Course Outline Bina Nusantara University}

\section{Course Description}

English Savry is for upper-beginner students with a PBT TOEFL soore of 433 - 463 (iBT TOEFL: 40 49150) to achieve a minimum iBT TOEFL score of 55 (PBT TOEFL- 480) with lower-intermediate-leved Acadernic English receptive skils and lower-intermediate-level Business English productive skills. The course is a pre-requisite program for English for Business Presentation.

\section{Graduate Competency}

Each Course in the study program contributes to the graduate competencies that are divided into employability and entrepreneurial skills and study program specific oustcomes, in which students need to heve demonstrated by the time they complete their course.

BINUS University employability and entrepreneurial skills consist of planning and organizing, proolem solving and decision making, self management. team work, communicaton, and inititive and enterprise.

This Course specifically focusas on the achievement of the following study program specific outcomes.

2.1. Study Program Specific Outcomes

\begin{tabular}{l}
\hline Study Program Spocific Outcomes \\
\hline $\begin{array}{l}\text { Graduates will able to demonstrate the lower-intermediate-level } \\
\text { Academic English listening skills }\end{array}$ \\
\hline $\begin{array}{l}\text { Graduates will able to demonstrate the lower-intermediate-level } \\
\text { Academic English reading skills }\end{array}$ \\
\hline $\begin{array}{l}\text { Graduates will able to demonstrate the lower-intermediate-level Business } \\
\text { English speaking skolls }\end{array}$ \\
\hline $\begin{array}{l}\text { Graduates will able to demonstrate the lower-intermediate-level Business } \\
\text { English writing skills }\end{array}$
\end{tabular}

3. Topics

- Basic Comprehension \& communication

- Vocabulary/Reference \& the future of business

- Pragmatic Understanding \& success

- Pragmatic Understanding 8 raising finance

- Vocabulary/Reference, Sentences \& Success

- Connecting information \& job satisfaction

- Details \& team building

- Listening review \& e-commerce

- Inferences \& takeoversimergers

- Reading to tearn \& risk

- Listening mini test \& crisis manegement

- Reading review \& International marketing 
ISBN 978-602-18907-2-1

- Reading mini test 8 Risk

4. Learning Outcomes

On successful completion of this Course, students will be able to

- LO1: demonstrate the bwer-intermediate-level Academic English listening skills of Basic Comprehension Pragmatic Understanding, and Connecting Information (B minimum of IBT TOEFL Listening scaled score of 14 of scale 30)

- LO2: demonstrate the lower-intermediate-level Acadernic Englisht reading skclis in Vocabulary \& Reference,

Le2: demonstrate the lower-intermediate-level Academic Englsht reading skclls in Vocabulary s Reference,
Sentences. Details, Inferences and Reading to leam (a minimum of iBT TOEFL Reading scaled score of 13 of scale 30)

- LO3: demonstrate the lower-intermediate-level Business English speaking skills in terms of Delivery, Ideas Development and Languaga (a minimum of BINUS English Speaking scaled score of 14 (wish minimum speaking rubric mean score of 1.83 ) of scale 30 )

- L04: demorstrate the lower-intermediate-level Business English writing skills in terms of Content, ideas Relationship and Language (a minimum of BINUS English Writing scaled score of 14 (with minimum writing rubric mean score of 2 . ) of scale 30 )

5. Teaching and Learning Strategies

In this course the locturers might deploy several teaching learning strategies, including lecturing, demonstration. case study, individual presentation, pair work, group work (role play), and homework.

6. Textbooks and Other Resources

6.1. Textbooks

1. Phillips, D. (2008) Longman Preparation Course for the TOEFL Test: IBT Listening. 2 ${ }^{\text {nd }}$ ed. Pearson Education. New York iseN 978-0-13-612658-4

2. Phillins $\mathrm{O}$ [2008] Longman Preparation Course for the TOFFL Test: IBT Reading $2^{\text {nd }}$ ed. Pearsen Education. New York ISBN; $978-0-13-612659-1$

3. Cotton, D., Falvey, D., \& Kent, S. (2001). Market Leader Course Book: Upper Intermediate Business English. 1" ed. Pearson Education Limited. Essex. ISBN: 0-582-434645.

The book in the first and second ist is a must to have for each student

\subsection{Other Resources}

1. http://www.performance-

appraisals.org/8acalsaspraisalarticles/articles/copcommunication.htm

2. hitp://findarticles.com/phartidesimi_m1249/is_n1_v71/ai_20370929/

3. http:i/www.bbraham comvdownioads/TipNegotiation.put

4. http://www.ventureplan.com/how.to,structure vour.deal.html

5. hitp: $/ / / \mathrm{ww}$ w brainstorming co. ukj

6. hitp:i/lwww. fastcompany.comimagazine/26/riskybiz.hitmil

7. http://www.fastcompany.com/magazine/57/riskreward.htm

B. http://www.performance-appraisals.org/Bacalsappraisalarticles/articles/conav. htm

9. http://humanresources about.com/od/involvementteams/a/twelve tip team.htm

10. http://nadabs.tripod.com/team/EffectiveTeamleaders.html

11. http://findarticles_com/p/articles/mi m05MG/is 1 20/ai 61298804/

12. http://www.mergernetwork.com/?GCID=C10625x001

13. http://www fastcompany.com/magozine/70/dispatches 1 html

14. http://www.crisismanagement.com/time.html 
ISBN 978-602-18907-2-1

7. Schedule

\begin{tabular}{|c|c|c|c|}
\hline $\begin{array}{l}\text { Sessionl } \\
\text { Mode }\end{array}$ & $\begin{array}{c}\text { Related } \\
\text { LO }\end{array}$ & Topics & References \\
\hline $\begin{array}{c}1 \\
F 2 F\end{array}$ & $\begin{array}{l}\text { LO } 1 \\
\text { LO } 3\end{array}$ & $\begin{array}{l}\text { Basic Comprehension \& communication } \\
\text { - Listening exercise: skilts } 1-2 \\
\text { - Telephoning: problem solving } \\
\text { - Sub Topic } \\
\text { - Sub Topic }\end{array}$ & 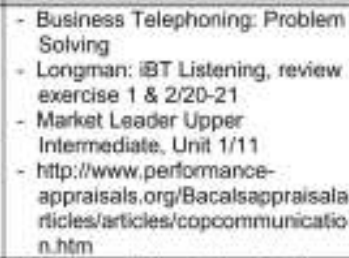 \\
\hline$\stackrel{2}{F 2 F}$ & $\begin{array}{l}\mathrm{LO} 2 \\
\mathrm{LO} 3\end{array}$ & $\begin{array}{l}\text { Vocabulary/Reference \& the future of } \\
\text { business } \\
\text { - Reading exercise: skils } 1 \cdot 2 \\
\text { - Telephoning: getting the right info } \\
\text { - Sub Topic } \\
\text { - Sub Topic }\end{array}$ & 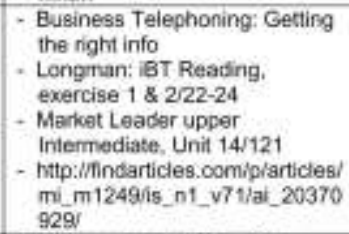 \\
\hline$\stackrel{3}{F}$ & $\begin{array}{l}101 \\
103\end{array}$ & $\begin{array}{l}\text { Pragmatic Understanding \& success } \\
\text { - Listening exercise: skills } 3-4 \\
\text { - Negotianting: } 3 \text { key skclls } \\
\text { - Sub Topic } \\
\text { - Sub Topic }\end{array}$ & $\begin{array}{l}\text { - Business Negotiating: } 3 \text { key } \\
\text { skills } \\
\text { - Longman: } 8 \text { T Listening. } \\
\text { exercise } 3 \& 4 / 39-40 \\
\text { - Market Leader Upper } \\
\text { Intermediate, Unit } 4 / 35 \\
\text { - http://wwww.bbraham,comvidowni } \\
\text { cads/TipNegotiation:pdt }\end{array}$ \\
\hline $\begin{array}{c}4 \\
F 2 F\end{array}$ & $\begin{array}{l}\text { LO } 1 \\
\text { LO } 3\end{array}$ & $\begin{array}{l}\text { Pragmatic Understanding } 8 \text { raising finance } \\
\text { - Listening review exercise: skcll } 1-4 \\
\text { - Negotiating: tochniques } \\
\text { - Sub Topic } \\
\text { - Sub Topic }\end{array}$ & $\begin{array}{l}\text { - Eusiness Negotiating: } \\
\text { Techniques. } \\
\text { - Longman: I8T Listening, reviaw } \\
\text { exercise 1-4/41-42 } \\
\text { - Market Leader upper } \\
\text { Intermediate, Unit 9/81 } \\
\text { - hitp:i/www.ventureplan.comho } \\
\text { w.to.structure.your.deal.him! }\end{array}$ \\
\hline $\begin{array}{c}5 \\
\text { GSLC }\end{array}$ & $\begin{array}{l}\mathrm{LO} 2 \\
\mathrm{LO} 4\end{array}$ & $\begin{array}{l}\text { Vocabulary/Reference, Sentences \& Success } \\
\text { - Reading exercise: skils } 3-4 \\
\text { - Reading review exercise: skills } 1-4 \\
\text { - Writing: business press release } \\
\text { - Sub Topic } \\
\text { - Sub Topic }\end{array}$ & $\begin{array}{l}\text { - [PowerPoint Trtie] } \\
\text { - Longman: BTT Reading, } \\
\text { exercise skill } 38 \text { \&/40-43 } \\
\text { - Longman: BT Reading, review } \\
\text { exercise skilis } 1-4 / 44-47 \\
\text { - Market Leader Upper } \\
\text { Intermediate, Unit 4/36-37,141 } \\
\text { - [Other Resources Title, URL] }\end{array}$ \\
\hline $\begin{array}{c}6 \\
\text { F2F }\end{array}$ & $\begin{array}{l}\text { LO } 1 \\
\text { LO3 }\end{array}$ & $\begin{array}{l}\text { Connecting Information \& job satisfaction } \\
\text { - Listening exercise: skills } 5-6 \\
\text { - Business Communication: handling } \\
\text { dificuel situations } \\
\text { - Sub Topic } \\
\text { - Sub Topic }\end{array}$ & 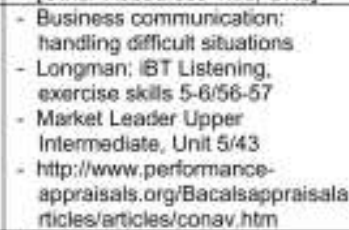 \\
\hline $\begin{array}{c}7 \\
F 2 F\end{array}$ & $\begin{array}{l}102 \\
103\end{array}$ & $\begin{array}{l}\text { Detsils } 8 \text { team builoing } \\
\text { - Reading exarcise: skilis 5-6 } \\
\text { - Business Communication. resolving } \\
\text { conflict } \\
\text { - Sub Topic }\end{array}$ & $\begin{array}{l}\text { - Business communication: } \\
\text { Resolving conftict } \\
\text { - Longman: BRT Rearing, } \\
\text { exercise skills 5-6/62-64 } \\
\text { - Market Leader upper }\end{array}$ \\
\hline
\end{tabular}


ISBN 978-602-18907-2-1

\begin{tabular}{|c|c|c|c|}
\hline & & - Sub Topic & $\begin{array}{l}\text { Intermodiato, Unit 8/73 } \\
\text { - htte://humanresources,a } \\
\text { bout.com/od/involvemen } \\
\text { tteams/a/twelve tip tea } \\
\text { m.htm } \\
\text { - hitp:linadabs tripod.comiteamiE } \\
\text { ffectiveTeamieaders htmil }\end{array}$ \\
\hline $\begin{array}{c}8 \\
\text { F2F }\end{array}$ & $\begin{array}{l}\text { LO } 1 \\
\text { LO } 3\end{array}$ & $\begin{array}{l}\text { Listening review \& e-commerce } \\
\text { - Listening review exercise: skalls 1-6 } \\
\text { - Presentation: Customers } \\
\text { - Sub Topic } \\
\text { - Sub Topic }\end{array}$ & 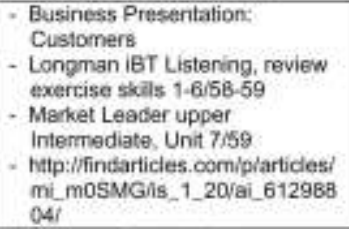 \\
\hline$\stackrel{9}{\mathrm{~F} 2 \mathrm{~F}}$ & $\begin{array}{l}\text { LO } 1 \\
\text { LO3 }\end{array}$ & $\begin{array}{l}\text { Inferences \& takeoversimergers } \\
\text { - Reading exercise: skils 7-8 } \\
\text { - Presentation: summarising } \\
\text { - Sub Topic } \\
\text { - Sub Topic }\end{array}$ & $\begin{array}{l}\text { - Business Presentation: } \\
\text { Summarizing } \\
\text { - Longman: iBT Reading, } \\
\text { exercise skdils 7-8/82-85 } \\
\text { - Market Leader Upper } \\
\text { Intermediate, Unit 13/113 } \\
\text { - hittp://Www.merpernetwork.comV } \\
\text { 7GCID=C10625x001 }\end{array}$ \\
\hline $\begin{array}{c}10 \\
\text { GSLC }\end{array}$ & $\begin{array}{l}\text { LO } 2 \\
\text { LO } 4\end{array}$ & $\begin{array}{l}\text { Reading fo learn } 8 \text { risk } \\
\text { - Reading exercise: skils } 9-10 \\
\text { - Writing: business report } \\
\text { - Sub Topic } \\
\text { - Sub Topic }\end{array}$ & 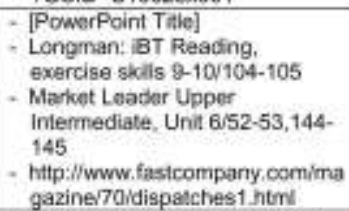 \\
\hline $\begin{array}{c}11 \\
F 2 F\end{array}$ & $\begin{array}{l}\mathrm{LO} 1 \\
\mathrm{LO}_{3}\end{array}$ & $\begin{array}{l}\text { Listening mini test \& crisis maniagement } \\
\text { - Listening minv test } 1 \text { no, } 1-5 \\
\text { - Presentation: Q \& A } \\
\text { - Sub Topic } \\
\text { - Sub Topic }\end{array}$ & $\begin{array}{l}\text { - Business Presentation: Q \& A } \\
\text { - Longman iBT Listening, mini } \\
\text { test } 1 \text { no, } 1-5 / 66-67 \\
\text { - Market Leader Upper } \\
\text { Intermediate, Unit } 11 / 97 \\
\text { - Hitp://wwww, crisismanagement.co } \\
\text { mulime.hitmi }\end{array}$ \\
\hline $\begin{array}{c}12 \\
\text { GSLC }\end{array}$ & $\begin{array}{l}\text { LO } 2 \\
\text { LO } 3\end{array}$ & $\begin{array}{l}\text { Reading review \& International marketing } \\
\text { - Reading review exercise: skills } 1-10 \\
\text { - Discussion brainstorming } \\
\text { - Sub Topic } \\
\text { - Sub Topic }\end{array}$ & $\begin{array}{l}\text { - Business Discussion: } \\
\text { Brainstorming } \\
\text { - Longman: BTT Reading, neview } \\
\text { exercise skills 1-10/106-109 } \\
\text { - Market Leader upper } \\
\text { Intermediate. Unit } 2 / 19 \\
\text { - http://www.tbrainstorming.co.LkJ }\end{array}$ \\
\hline $\begin{array}{c}13 \\
F 2 F\end{array}$ & $\begin{array}{l}\mathrm{LO} 2 \\
\mathrm{LO} 3\end{array}$ & $\begin{array}{l}\text { Reading mini test \& Risk } \\
\text { - Reading: mini test } 1 \text { no. 1-13 } \\
\text { - Discussion: reaching agreement } \\
\text { - Sub Topic } \\
\text { - Sub Topic }\end{array}$ & 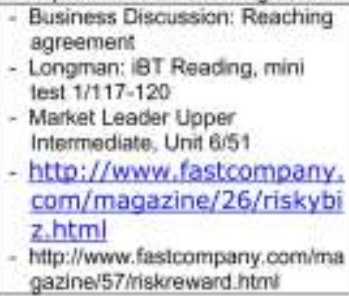 \\
\hline
\end{tabular}


Laboratory

\begin{tabular}{|c|c|c|c|}
\hline $\begin{array}{l}\text { Session' } \\
\text { Mode }\end{array}$ & $\begin{array}{c}\text { Related } \\
\text { Lo }\end{array}$ & Topics & References \\
\hline $\begin{array}{c}{[99]} \\
{[\mathrm{F} 2 \mathrm{~F}]}\end{array}$ & LO [9] & $\begin{array}{l}\text { [Topic] } \\
\text { - Sub Topic } \\
\text { - Sub Topic } \\
\text { - Sub Topic } \\
\text { - Sub Topic }\end{array}$ & $\begin{array}{l}\text { - [PowerPoint Titie] } \\
\text { - [Book Titie, Chapteripages] } \\
\text { - [Other Resources Titie] } \\
\text { - [Other Rescurces Tites, URL] }\end{array}$ \\
\hline $\begin{array}{c}{[99]} \\
{[\mathrm{F} 2 \mathrm{~F}]}\end{array}$ & LO [9] & $\begin{array}{l}\text { [Topic] } \\
\text { - Sub Topic } \\
\text { - Sub Topic } \\
\text { - Sub Topic } \\
\text { - Sub Topic }\end{array}$ & $\begin{array}{l}\text { - [PowerPoint Title] } \\
\text { - [Book Titie, Chapteripages] } \\
\text { - [Other Resources Titie] } \\
\text { - [Other Resources Title, URL] }\end{array}$ \\
\hline $\begin{array}{c}{[99]} \\
{[\mathrm{F} 2 \mathrm{~F}]}\end{array}$ & LO [9] & $\begin{array}{l}\text { [Topic] } \\
\text { - Sub Topic } \\
\text { - Sub Topic } \\
\text { - Sub Topic } \\
\text { - Sub Topic }\end{array}$ & $\begin{array}{l}\text { - [PowerPont Title] } \\
\text { - [Book Tite, Chapteripages] } \\
\text { - [Other Resources Titie] } \\
\text { - [Other Resources Titie, URL] }\end{array}$ \\
\hline
\end{tabular}

8. Evaluation

Theory

\begin{tabular}{|l|c|c|c|c|c|c|c|}
\hline \multirow{2}{*}{ Assessment Activity } & \multirow{2}{*}{ Weight } & \multicolumn{5}{|c|}{ Learning Outcomes } \\
\cline { 4 - 8 } & & 1 & 2 & 3 & 4 & 5 & 6 \\
\hline $\begin{array}{l}\text { Independent Assignment 1+ Mid } \\
\text { Exam }\end{array}$ & $50 \%$ & $v$ & $\vee$ & $v$ & $\vee$ & & \\
\hline $\begin{array}{l}\text { Independent Assignment 2+ Final } \\
\text { Exam }\end{array}$ & $50 \%$ & $v$ & $\vee$ & $v$ & $v$ & & \\
\hline
\end{tabular}

Laboratory

\begin{tabular}{|c|c|c|c|c|c|c|c|}
\hline \multirow{2}{*}{ Assessment Activity } & \multirow{2}{*}{ Weight } & \multicolumn{6}{|c|}{ Learning Outcomes } \\
\hline & & 1 & 2 & 3 & 4 & 5 & 6 \\
\hline Independent Assignment & {$[99] \%$} & & & & & & \\
\hline [Quiz] & {$[99] \%$} & & & & & & \\
\hline [Praject] & {$[99] \%$} & & & & & & \\
\hline Mid Exam & {$[99] \%$} & & & & & & \\
\hline Final Exam & {$[99] \%$} & & & & & & \\
\hline
\end{tabular}

Final Evaluation Score

\begin{tabular}{|l|r|}
\hline Aspects & Weight \\
\hline Theory & $100 \%$ \\
\hline
\end{tabular}

